\title{
APLIKASI GESTALT PADA DESAIN LABEL KEMASAN PRODUK AQUA
}

\author{
Nova Kristiana \\ Jurusan Desain, fakultas Bahasa dan Seni \\ Universitas Negeri Surabaya \\ novakristiana@unesa.ac.id
}

\begin{abstract}
Abstrak
Dalam suatu produk, elemen Positioning, differensiasi dan Brand merupakan tiga hal pokok yang harus dipertimbangkan dalam sebuah kemasan. Desain kemasan yang menarik mampu membuka ruang tersendiri di benak konsumen melalui komunikasi visual. Danone perusahaan asal Perancis mengeluarkan desain kemasan yang khusus. Desain kemasan produk air mineral Aqua pada botol minuman ukuran $600 \mathrm{ml}$, bertema 'Temukan Indonesiamu" dengan mengangkat tema budaya lokal Indonesia, terdiri dari 5 judul yaitu Berbagi, Santun, Ramah, Kekeluargaan, dan Gotong Royong. Dari kelima seri tersebut ada dua judul yaitu Santun dan Gotong-Royong yang dalam memvisualkannya menggunakan teori Gestalt. Penelitian ini menggunakan metode deskriptif kualitatif dimana teori Gestalt, selanjutnya dideskripsikan dan dianalisis secara kualitatif. Hasil dari penelitian ini yaitu adanya pesan yang mendalam dari kedua desain kemasan tersebut.
\end{abstract}

Kata Kunci: desain kemasan, gestalt, aqua

\begin{abstract}
There are three considered key points in a product packaging: positioning, differentiation and brand. A visually attractive packaging design is able to open its own space in the minds of consumers. Danone Company of France issued a special packaging design. The design of Aqua mineral water product packaging at $600 \mathrm{ml}$ bottle beverage, themed 'Discover Indonesiamu' with the theme of Indonesian lokal culture, consists of 5 titles: Sharing, Politeness, Friendly, Kinship, and Cooperation. Of the five series there are two titles namely Politeness and Cooperation which in visualizing using the theory of Gestalt. This research uses qualitative descriptive method in which Gestalt theory, hereinafter described and analyzed qualitatively. The result of this research is the deep message of both packaging designs.
\end{abstract}

Keywords: packaging design, gestalt, aqua 


\section{PENDAHULUAN}

Pada era globalisasi seperti sekarang ini dimana situasi persaingan perdagangan dalam pasar semakin ketat. Persaingan yang semakin ketat menuntut adanya strategi khusus dalam menghadapinya. Persaingan produk tidak lagi terbatas pada kualitas produk, namun pada usaha untuk mendapatkan nilai tambah dari konsumen dan calon konsumen. Sehingga perusahaan sebagai produsen dituntut untuk selalu berkembang dan berinovasi terhadap produknya. Untuk merebut perhatian konsumen, produsen mengembangkan beberapa strategi antara lain positioning produk, differensiasi produk, dan pembangunan brand value. Selain strategi memperkuat produk, salah satu strategi lainnya adalah membuat kemasan yang menarik pada produk.

Kemasan produk makanan dan minuman berbeda dalam desain labelnya. Desain kemasan makanan ringan menutupi semua isi atau produknya, kemasan pada air mineral sebagian besar yang beredar memperlihatkan isi atau produknya. Menggunakan botol bening supaya produk yang ada didalamnya terlihat jernih, dan menyegarkan. Desainer memiliki ruang atau space yang terbatas untuk membuat labelnya. Perusahaan air mineral semakin bermunculan, sejalan dengan pertumbuhan jumlah penduduk yang semakin pesat, maka kebutuhan akan air bersih dan sehat juga semakin bertambah. Perusahaan air mineral bersaing semakin ketat untuk merebut pangsa pasar dan konsumen yang baru. Selain meningkatkan kualitas produksinya dengan embel-embel kesehatan dengan kadar alkali, kadar oksigen.

Berbagai macam merek air mineral bermunculan dan dikenal oleh masyarakat antara lain Aqua, Cleo, Aquaria, Club, Ades, Vit, Indomaret, Unesa dan berbagai merek lainnya. Banyaknya merek air mineral yang beredar di pasaran, hal ini membuat para konsumen dan calon konsumen benar-benar selektif dalam mengambil keputusan untuk menentukan merek apa yang akan dibeli dan selanjutnya dikonsumsi. Konsumen secara jelas cenderung bersikap rasional dan selektif terhadap pembelian barang yang diinginkannya baik kualitas produk maupun harganya. Untuk memutuskan membeli salah satu merek air mineral, konsumen mempertimbangkan kebersihan dan harga produk serta manfaatnya bagi kesehatan, karena air mineral merupakan bahan kebutuhan utama bagi konsumen.

Salah satu unsur produk yang sering diperhatikan konsumen selain harga dan kualitas produk adalah merek produk. Perusahaan air mineral membuat merek yang solid dan bersaing menempatkan merek mereka kepada benak konsumen. Brand trust merupakan salah satu skala yang bisa digunakan dalam mengukur rasa suka (preferensi) konsumen pada merek, dan berhubungan dengan tingkat loyalitas konsumen terhadap suatu merek (Aaker, 2008:67). Konsumen tidak hanya membeli satu kali air mineral namun pembelian konsumen terhadap produk yang sudah dirasa cocok akan dilakukan berulang-ulang hingga muncul produk sejenis yang kualitasnya lebih baik. Merek yang dipercaya oleh konsumen biasanya adalah merek yang akan sering dibeli oleh konsumen (Chauddhuri dan Holbrook, 2001:84). Sehingga pengaruh pembelian yang berulang-ulang sangat besar terhadap keberlangsungan produk serta perusahaannya. 
Salah satu produk perusahaan multinasional asal perancis Grup Danone yaitu Aqua. Aqua merupakan merk produk air mineral dalam kemasan yang sekitar 40 tahun lebih menjadi prioritas utama konsumen dalam memilih air mineral. Hingga saat ini melalui proses yang higienis, kemasan Aqua terdiri dari botol plastik $330 \mathrm{ml}, 600 \mathrm{ml}, 750 \mathrm{ml}$, $1500 \mathrm{ml}$, kemasan gelas plastik $240 \mathrm{ml}$, dan kemasan galon 19lt. berbagai varian ukuran kemasan tersedia memenuhi bermacam-macam kebutuhan konsumen akan adanya Aqua.

Bertepatan dengan ulang tahun ke-40, Aqua menghadirkan nuansa baru pada kemasannya. Melalui tema "Temukan Indonesiamu" Aqua mencoba menumbuhkan rasa keindonesiaan para pemuda di Indonesia. Dengan melibatkan campur tangan generasi muda, bersama Aqua dan kemasannya, Aqua membuat ajang lomba mendesain label kemasan Aqua. Generasi muda diajak untuk menggali kekayaan lokal Indonesia yang diangkat dalam karya visual baik itu fotografi, desain grafis maupun video. Kekayaan lokal itu berupa kebudayaan, kesenian, maupun aktivitas sehari-hari masyarakat Indonesia. Salah satu mata lomba yaitu mendesain label kemasan Aqua botol $600 \mathrm{ml}$. dari lomba tersebut banyak karya-karya generasi muda bermunculan dan benar-benar dijadikan label kemasan.

Salah satu seri pada tema 'temukan Indonesiamu' adalah gambaran aktivitas keseharian masyarakat Indonesia antara lain dengan judul Berbagi, Santun, Ramah, Kekeluargaan dan Gotong royong. Kelima judul itu divisualisasikan dengan gaya ilustrasi yang berbeda-beda. Gaya ilustrasi dengan muatan gestalt didalamnya ada dua yaitu kemasan yang berjudul Santun dan Gotong royong.

\subsection{Kemasan}

Kemasan merupakan salah satu unsur dari sebuah produk yang menjadi daya tarik oleh konsumen. Kemasan yang berfungsi melindungi, membungkus, serta menutupi isi dari produk dibuat semenarik mungkin dan elemen estetis diterapkan pada sisi kemasan. Elemen estetis tersebut digunakan untuk merangkai Informasi mengenai produk yang harus ada pada kemasan.

Kotler dan Amstrong (2012) mendefinisikan "packaging involves designing and producing the container or wrapper for a product" yang artinya adalah proses kemasan melibatkan kegiatan mendesain dan memproduksi, fungsi utama dari kemasan sendiri yaitu untuk melindungi produk agar produk tetap terjaga kualitasnya. Kemasan merupakan kegiatan perancangan dan produksi tempat sebuah produk. Kemasan meliputi 3 hal yaitu merek, kemasan itu sendiri, dan label.

Sebuah kemasan harus memiliki tampilan yang menarik. Daya tarik pada kemasan dapat digolongkan menjadi dua yaitu daya tarik visual (estetika) dan daya tarik praktis (fungsional). Unsur-unsur grafis yang tersusun pada kemasan akan menciptakan suatu kesan. Selain itu sebuah kemasan harus memiliki efektifitas dan efisiensi yang ditunjukkan kepada konsumen distributor (Dameria:2014 : 52). Daya tarik visual (estetika) mengacu pada penampilan grafis dari kemasan tersebut. Grafis visual ini 
meliputi bahan-bahan yang melekat pada produk, logo, dan label. Daya tarik praktis (fungsional) merupakan bentuk fisik kemasan yang berorientasi pada distribusi dan paska pemakaian.

Kemasan yang berhasil merupakan perpaduan antara pemasaran dan desain, maka sebuah kemasan harus memiliki kriteria-kriteria sebagai berikut; Menonjol (stand out) yaitu jika kemasan tidak atau kurang menonjol maka kemasan tersebut akan kehilangan fungsinya. Isi (content) yaitu kemasan harus dapat memberikan informasi tentang isi kemasan dan apa yang terkandung dalam produk harus diinformasikan pada kemasan. Unik (distinctive) yaitu kemasan dilihat secara keseluruhan harus unik dan berbeda dengan produk lain yang sejenis. Sesuai (suitable) yaitu desain kemasan harus sesuai dengan produk yang dikemas. (Dameria: 2014 : 54) Karakter kemasan harus mencitrakan karakter produknya.

\subsection{Gestalt}

Gestalt merupakan salah satu teori dalam membedah karya desain komunikasi visual. Gestalt adalah sebuah istilah yang berarti 'kesatuan yang utuh'. Teori gestalt menjelaskan proses penyatuan komponen-komponen yang berbeda sehingga membentuk visual atau pola yang memiliki unsur kemiripan dan menjadi kesatuan yang utuh. Teori gestalt mengacu pada teori persepsi visual yang dikembangkan oleh psikolog dari Jerman tahun 1920 (Anggraeni dan Nathalia, 2014:47). Teori gestalt digunakan untuk memprediksi reaksi pengamat dalam merespon sebuah karya seni dan desain karena banyak menjelaskan bagaimana persepsi visual bisa terbentuk. Mata sebagai indera pengamatan (visual) erat kaitannya dengan pembentukan persepsi manusia. Dengan hanya melihat sesuatu hal maka otak akan merespon dan menterjemahkan dalam bentuk interpretasi. Otak mempersepsikan objek visual dengan cara mengorganisasikan komponen-komponen sensasi yang memiliki hubungan, pola, ataupun kemiripan menjadi kesatuan. Hal seperti itulah yang disebut persepsi visual (Khamadi, 2015:100)

Teori gestalt mengembangkan lima hukum persepsi yang mengendap sebagai kecenderungan pemahaman manusia terhadap visual benda yang dilihatnya keenam hukum persepsi tersebut antara lain :

1. Kedekatan posisi (proximity). Elemen-elemen yang saling berdekatan akan dipersepsikan sebagai obyek yang sama dalam satu kelompok.

2. Kesamaan bentuk (similiarity). Elemen-elemen yang tampak sama akan dipahami sebagai bagian dari sebuah bentuk.

3. Kesinambungan pola (continuity). Elemen-elemen yang disusun secara berkesinambungan akan dipahami sebagai bentuk baru yang memiliki alur. Alur tersebut sebagai penghantar jalannya visual dalam melihat karya.

4. Penutupan bentuk (closure). Pengamat cenderung menghubungkan atau meneruskan alur menjadi sebuah bentuk dan melupakan sapce yang terputus. Jadi garis atau elemen yang terputus seakan-akan menyambung dan tidak diperhatikan lagi karena tertutupi oleh sebuah bentuk yang dituntun oleh alur. 
5. Gambar dan latar belakang (Figure and Ground). Kecenderungan dalam melihat karya adalah adanya obyek atau figure dan latar belakangnya atau background. Dalam beberapa karya desain figure sekaligus ground ataupun sebaliknya.

Inti dari teori gestalt ini yaitu elemen yang dipadupadankan sedemikian rupa bisa membentuk persepsi baru yang mungkin bisa saja berbeda dari elemen awalnya. Persepsi ini muncul berbeda-beda tergantung dari tingkat pengalaman visual orang yang melihat karya tersebut.

\section{METODE PENELITIAN}

Jenis penelitian ini adalah penelitian deskriptif kualitatif. Metode penelitian kualitatif digunakan untuk meneliti desain label kemasan air mineral Aqua yang pada saat itu memiliki label kemasan khusus dengan tema 'Temukan Indonesiamu". Data-data yang diperoleh dikumpulkan, dikelompokkan, disusun dan dideskripsikan dianalisis serta disimpulkan.

Data-data dikumpulkan melalui dokumentasi label kemasan Aqua edisi khusus dengan tema yang sama. Data-data tersebut direduksi. Dari kesekian desain ada satu tema 'temukan Indonesiamu' yang sekaligus mengeluarkan satu seri label kemasan meliputi berbagi, santun, ramah, kekeluargaan dan gotong-royong. Lima desain tersebut diambil dua desain yang sesuai dengan kajian literatur yakni teori gestalt. Analisis data dalam penelitian kualitatif merupakan proses penyusunan data secara sistematis yang diperoleh dari teknik pengumpulan data (observasi dan dokumentasi) kemudian dipelajari dan disimpulkan agar mudah dipahami (Sugiyono, 2011:335). Dua desain yang dianalisis dengan menggunakan teori gestalt yaitu Santun dan Gotong-royong. Setelah dianalisis maka tahap terakhir yaitu ditarik kesimpulan.

\section{HASIL DAN PEMBAHASAN}

Pada label kemasan khusus Aqua botol $600 \mathrm{ml}$ dengan tema \#Temukan Indonesiamu. Mengangkat tema tentang budaya lokal Indonesia meliputi berbagi, santun, ramah, kekeluargaan dan gotong royong.

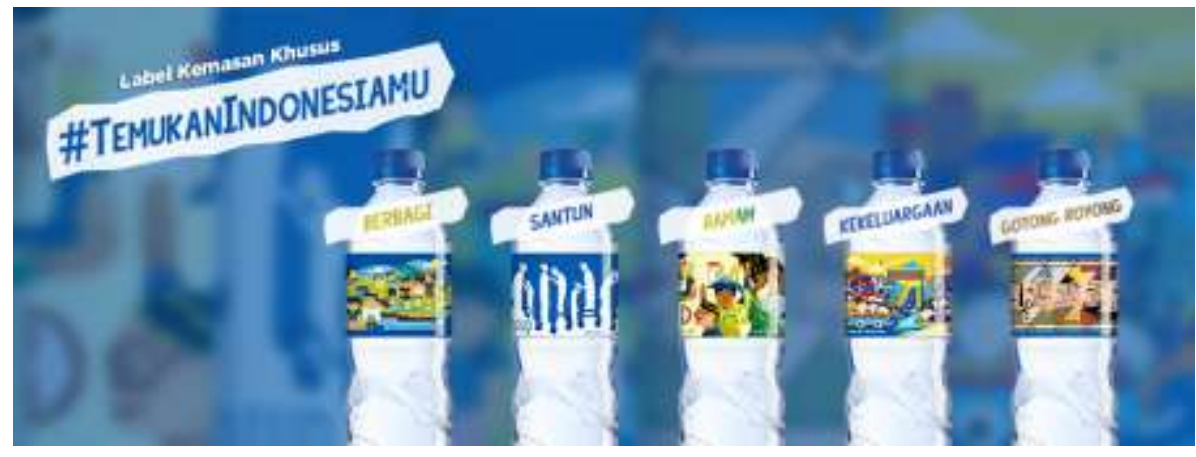

Gambar 1. Label kemasan khusus Aqua [Sumber : www.temukanindonesiamu.com] 
Pada gambar 2 Label kemasan dengan judul Santun, ditampilkan dengan layout mendatar. Dengan pewarnaan yang minimalis 2 warna sebagai figure dan ground. Meskipun dengan tampilan minimalis, namun pesan yang dibawa tersampaikan kepada khalayak. Label kemasan tersebut dipasang pada kemasan air mineral Aqua botol $600 \mathrm{ml}$.

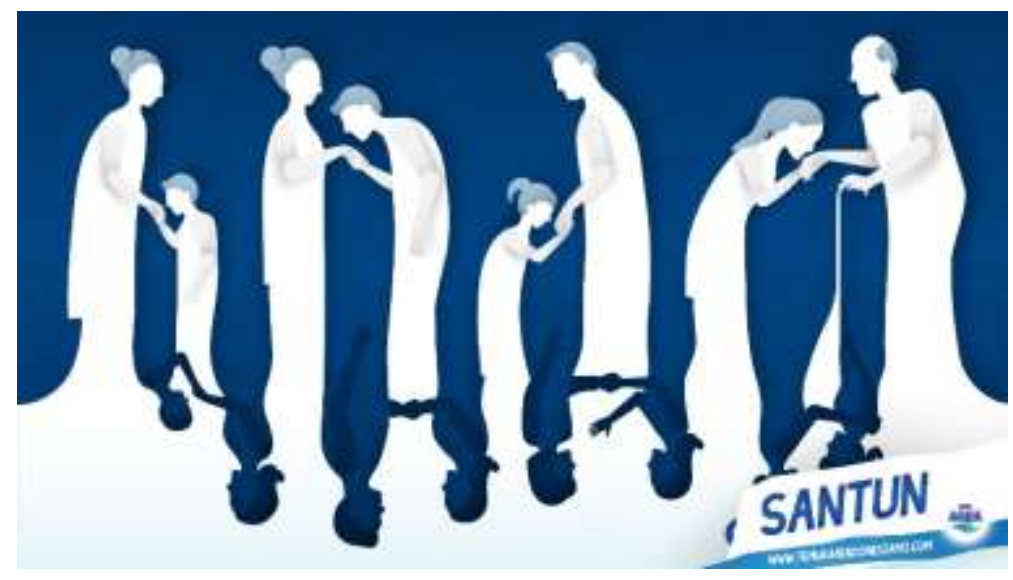

Gambar 2. Label kemasan khusus Aqua judul Santun [Sumber : www.temukanindonesiamu.com]

Pada label kemasan di atas sekilas dilihat ada 8 orang saling berjabat tangan. Beberapa orang ditampilkan berbeda menunjukkan usia yang berbeda pula. Dari sebelah kiri antara lain sosok wanita tua digambarkan dengan rambut yang digelung posisi tubuh agak membungkuk tangan kanan ke depan menunjukkan bahwa itu adalah sosok wanita tua berjabat tangan dengan anak laki-laki. Anak laki-laki tersebut digambarkan dengan tubuh kecil, pendek, rambut cepak, dan berjabat tangan dengan mencium tangan wanita tua. Hal ini menunjukkan hubungan usia yang jauh antara anak laki-laki dengan wanita tua tersebut. Di Indonesia anak kecil dalam berjabat tangan wajib mencium tangan orang yang jauh lebih tua. Obyek berikutnya yaitu wanita dewasa atau paruh baya bisa dikatakan wanita ini adalah seorang ibu dengan visual rambut yang digelung, dan dalam posisi badan masih tegak dalam berjabatan tangan dengan laki-laki remaja. Lelaki ini ditunjukkan dengan postur tubuh yang sedang, rambut cepak, dan mencium tangan dalam berjabat tangan. Hal ini menunjukkan bahwa di Indonesia gaya dalam berjabat tangan antara dua sosok yang berbeda usia yaitu dengan cara mencium tangan. Berikutnya yaitu digambarkan dengan anak perempuan yang digambarkan dengan postur tubuh kecil, rambut diikat. Gaya berjabat tangan mencium tangan seorang laki-laki dewasa. Laki-laki dewasa ini ditunjukkan dengan postur tubuh yang besar, rambut cepak agak botak. Obyek berikutnya adalah sosok remaja wanita ditunjukkan dengan postur tubuh sedang, dengan rambut panjang diikat, bersalaman dengan mencium tangan seorang laki-laki yang sudah tua. Laki-laki tua tersebut ditunjukkan dengan postur tubuh yang sudah mulai membungkuk, rambut botak, dan tangan kiri memegang tongkat sebagai alat bantu penyangga tubuhnya. 


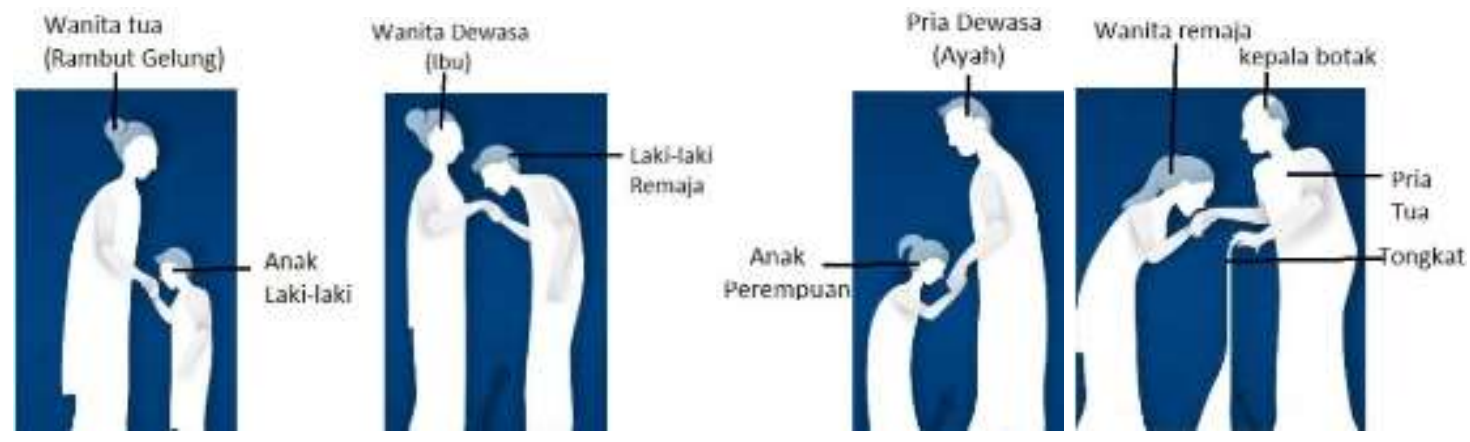

Gambar 3. Analisis elemen label kemasan khusus Aqua judul Santun [Sumber: Penulis]

Dari beberapa sosok pada gambar di atas digambarkan gaya berjabat tangan yang sama yaitu dengan cara mencium tangan. Gaya ini menunjukkan adanya sikap sopan santun menghormati kepada orang yang lebih tua. Jika bertemu dengan orang yang sekiranya lebih tua maka wajib menyapa, menyalami dan mencium tangannya. Analisis pada gambar di atas secara garis besar terlihat sosok yang saling bersalaman. Namun jika diamati lebih jauh akan ada dua obyek yang terlihat. Dalam teori gestalt Jika stimulus mengandung dua atau lebih daerah yang berbeda, biasanya akan dilihat sebagiannya sebagai gambar atau sosok dan sisanya sebagai background atau latar belakang atau biasa disebut sebagai figure dan ground. Daerah yang terlihat pada gambar berisi obyek akan menjadi pusat perhatian dan dibaca lebih awal. Mereka tampak lebih padat dibandingkan latar belakang dan terlihat di depan latar. Inilah bentuk organisasi perseptual yang paling dasar. Proses persepsi tersebut yang akan berusaha membedakan obyek dari latar dalam keadaan yang sebanding obyek dan latar dapat dipertukarkan sehingga menghasilkan hubungan ambiguitas atau keduanya. Kita mesti mendefinisikan tanda bukan lagi menurut 'komposisinya' tetapi dengan memperhitungkan hal-hal yang menjadi latar keberadaannya ini merupakan perkara nilai (Barthes, 2012:50).

Jika label pada gambar di atas dibalik $180^{\circ}$ maka akan dilihat gambar yang berbeda. Seperti gambar di bawah ini

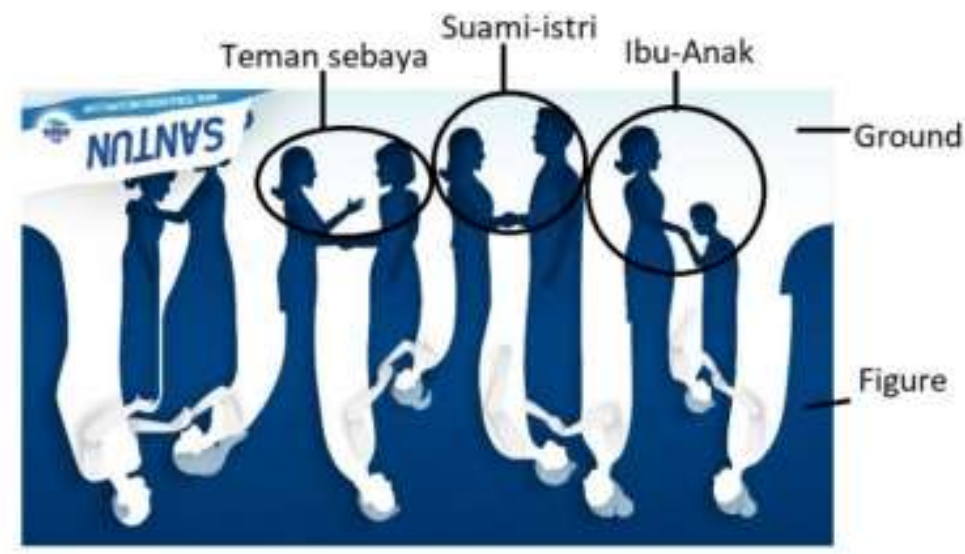

Gambar 4. Analisis elemen label kemasan khusus Aqua judul Santun (dibalik) [Sumber: Penulis] 
Pada gambar 4, sama halnya dengan gambar sebelumnya yaitu adanya dua sisi obyek dan background. Sama-sama sosok yang saling berjabat tangan dengan jumlah orang yang sama. Namun ada beberapa yang membedakan diantaranya, pada obyek pertama digambarkan seorang remaja wanita dengan wajah tertunduk saat berhadapan dengan seorang wanita dewasa. Tangan wanita tersebut merengkuh pundak remaja wanita. Obyek berikutnya yaitu dua wanita berpostur tubuh yang sama tingginya, dengan rambut pendek sebahu dibiarkan terurai, keduanya tampak saling berpegangan tangan, bertemu, dan bercakap-cakap. Menandakan bahwa keduanya adalah sebaya. Berikutnya digambarkan sosok wanita dewasa ditunjukkan dengan postur tubuh yang tinggi, dengan rambut dibiarkan terurai, saling berpegangan tangan dengan seorang lelaki dewasa yang ditunjukkan dengan postur yang tinggi, rambut cepak, dan keduanya saling berhadapan dan saling berpegangan tangan. Hal ini menunjukkan hubungan yang dekat diantara keduanya. Obyek berikutnya yaitu sosok ibu muda dengan postur tubuh yang tinggi, rambut terurai, tangan kanannya menyalami seorang anak laki-laki yang ditunjukkan dengan postur tubuh kecil pendek serta potongan rambut yang cepak, tangan kanan menyalami ibu dan mencium tangan ibu.

Dari gambaran di atas menunjukkan bahwa gaya bergaul, gaya menyapa yang berbeda-beda. Gaya menyapa dengan teman sebaya, cukup berjabat tangan, suamiistri saling memegang tangan memberikan kepercayaan dan kedekatan, antara ibu anak gaya menyapanya yaitu dengan mencium tangan ibunya. Gaya yang berbedabeda ini menunjukkan keberagaman cara bersopan santun yang ada di masyarakat Indonesia.

Satu gambar yang terdiri dari figure dan ground, jika dibalik memiliki pesan yang berbeda. Pada pesan pertama Figure memuat pesan bahwa berjabat tangan dengan cara mencium tangan dilakukan oleh orang-orang yang terpaut usia cukup jauh, namun jika gambar tersebut dibalik, yang tadinya ground menjadi figure memuat pesan cara menyapa, cara bersopan santun, bagaimana memperlakukan teman sebaya, pasangannya, ibu dan anak, dan anak jika sudah menginjak remaja itu berbeda.

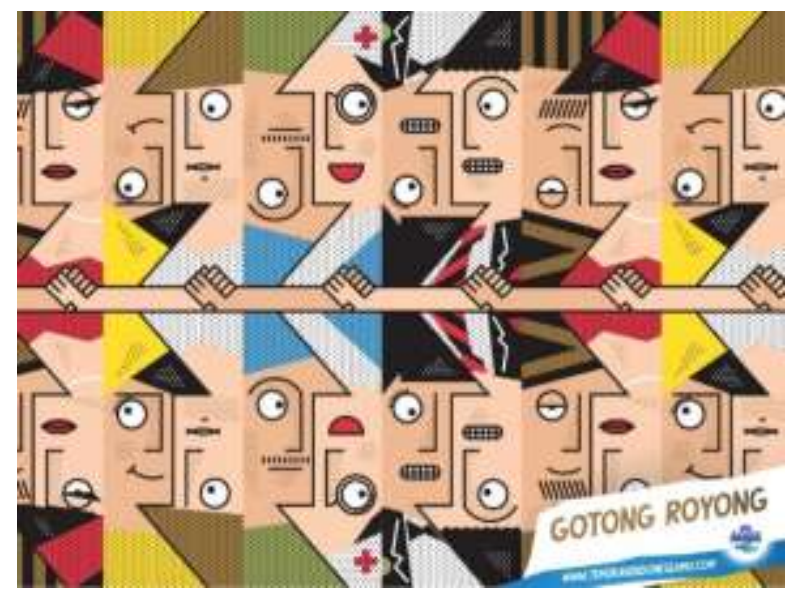

Gambar 5. Label kemasan khusus Aqua judul Gotong Royong [Sumber : www.temukanindonesiamu.com] 
Pada desain label kemasan dengan judul Gotong Royong di gambar 5 merupakan gabungan obyek-obyek yang memiliki elemen sama namun berbeda maknanya. Elemen garis yang membentuk bidang pada setiap objek sama. Susunannya seakanakan berulang namun berbeda detail visualnya.

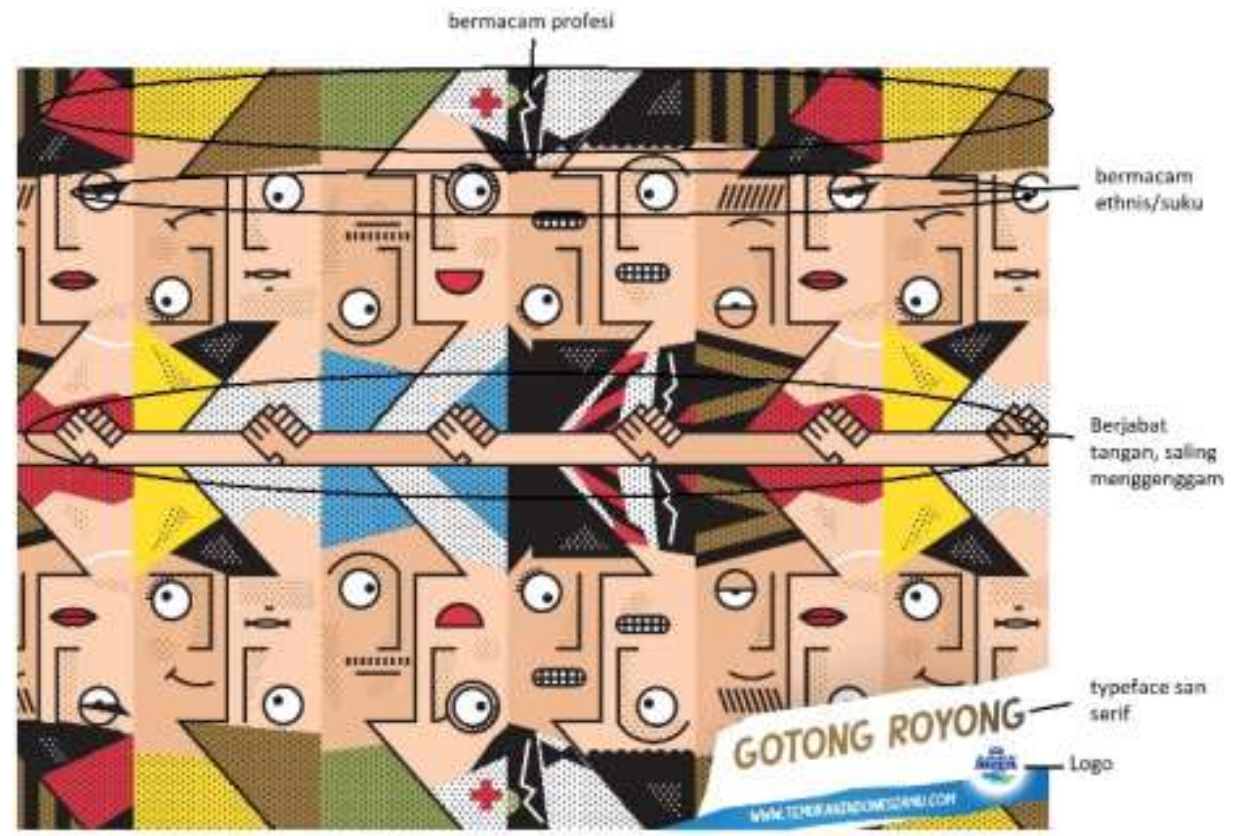

Gambar 6. Analisis elemen label kemasan khusus Aqua judul Gotong Royong [Sumber: Penulis]

Pada gambar di atas pada bagian atas dan bawah pada dasarnya sama. Namun secara detail terletak pada bagian atas setiap obyek.

Tabel 1: Analisis formal dan persepsi label kemasan Aqua judul Gotong Royong [Sumber: Penulis]

\begin{tabular}{|c|l|l|l|}
\hline No & \multicolumn{1}{|c|}{ Analisis Formal } & \multicolumn{1}{c|}{ Persepsi } \\
\hline & $\begin{array}{l}\text { - Topi Segitiga warna merah } \\
\text { hitam } \\
\text { - Mata Bulat dengan bulu } \\
\text { mata lentik }\end{array}$ & $\begin{array}{l}\text { - Topi pramusaji } \\
\text { - Wanita cantik } \\
\text { - Murah senyum, } \\
\text { ramah }\end{array}$ \\
\hline 2 & $\begin{array}{l}\text { - Bibir merah } \\
\text { - Badan seksi }\end{array}$ & \\
\hline
\end{tabular}




\begin{tabular}{|c|c|c|c|}
\hline No & Gambar & Analisis Formal & Persepsi \\
\hline 3 & & $\begin{array}{l}\text { - Topi warna putih dengan } \\
\text { penambahan simbol palang } \\
\text { merah } \\
\text { - memakai kacamata } \\
\text { - Mulut terbuka dengan bibir } \\
\text { merah }\end{array}$ & $\begin{array}{l}\text { - petugas medis / } \\
\text { kesehatan } \\
\text { - teliti } \\
\text { - murah senyum }\end{array}$ \\
\hline 4 & & $\begin{array}{l}\text { - topi hitam kombinasi putih } \\
\text { - berdasi hitam putih } \\
\text { - mulut terbuka kelihatan } \\
\text { giginya }\end{array}$ & $\begin{array}{l}\text { - pengabdi negara } \\
\text { - ramah, murah } \\
\text { senyum }\end{array}$ \\
\hline 5 & & $\begin{array}{l}\text { - Topi Segitiga kuning hitam } \\
\text { - Mata Bulat } \\
\text { - Bibir tertarik kesamping }\end{array}$ & $\begin{array}{l}\text { - Buruh } \\
\text { - Pemuda } \\
\text { - Murah senyum }\end{array}$ \\
\hline 6 & & $\begin{array}{l}\text { - Topi berwarna biru } \\
\text { - Mata Bulat } \\
\text { - Berkumis } \\
\text { - Baju hijau }\end{array}$ & $\begin{array}{l}\text { - Masyarakat } \\
\text { biasa } \\
\text { - Laki-laki dewasa }\end{array}$ \\
\hline 7 & & $\begin{array}{l}\text { - Topi berwarna hitam } \\
\text { - Mata Bulat } \\
\text { - Berdasi kupu hitam } \\
\text { - Memakai jas }\end{array}$ & $\begin{array}{l}\text { - Laki-laki } \\
\text { - Pekerja kantoran } \\
\text { - semangat }\end{array}$ \\
\hline 8 & Gotor & $\begin{array}{l}\text { - Topi berwarna hitam bergaris } \\
\text { cokelat } \\
\text { - Mata Bulat agak sipit } \\
\text { - Bibr berbentuk garis } \\
\text { lengkung U }\end{array}$ & $\begin{array}{l}\text { - Laki-laki dewasa } \\
\text { - Murah senyum } \\
\text { - budayawan }\end{array}$ \\
\hline 9 & 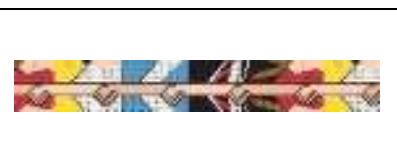 & Tangan saling mengepal & $\begin{array}{l}\text { - Berjabat tangan } \\
\text { - Persatuan } \\
\text { - Gotong royong }\end{array}$ \\
\hline
\end{tabular}

Berdasarkan analisis tabel di atas, digambarkan sosok yang berbeda-beda. Hal ini menunjukkan bahwa masyarakat Indonesia dengan beragam profesinya, tidak membeda-bedakan, baik laki-laki perempuan, dewasa pemuda dari berbagai kalangan memiliki semangat persatuan, gotong royong bagi tujuan dan kepentingan bersama. 
Penggambaran mata dengan berbagai bentuk dan ukuran. Menunjukkan etnis atau suku yang beranekaragam dan ekspresi yang bermacam-macam mampu bersatu bergotong royong tanpa adanya pembedaan.

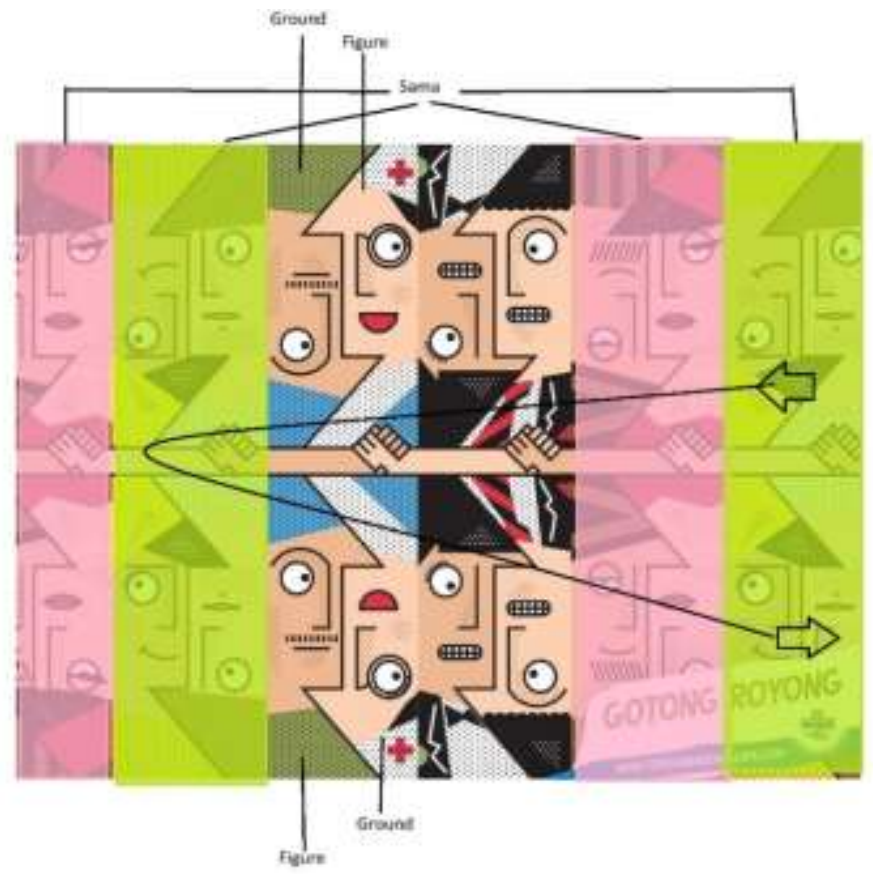

Gambar 7. Analisis gestalt label kemasan khusus Aqua judul Gotong Royong [Sumber: Penulis]

Pada gambar di atas, ada dua proses dalam seleksi yaitu perhatian (attention) dan persepsi selektif (Selective perception). Perhatian yang dilakukan oleh pengamat dapat terjadi secara sengaja dan tidak sengaja. Perhatian yang disengaja disebut sebagai voluntary attention, dimana pengamat secara aktif mencari informasi yang mempunyai relevansi pribadi. Sedangkan persepsi selektif terjadi ketika pengamat melakukan voluntary attention. Ketika pengamat memiliki keterlibatan yang tinggi terhadap karya desain, maka pada saat itu pengamat mengalami bisa disebut melakukan proses perhatian selektif. Proses perhatian selektif terjadi karena karena dengan mempunyai keterlibatan yang tinggi terhadap suatu karya desain, berarti pengamat telah secara aktif mencari informasi mengenai karya tersebut dari berbagai sumber (Tanudjaja, 2005:59).

Pada label kemasan di atas seseorang yang melihat sekilas merasakan gambar-gambar itu adalah gambar yang sama hanya diulang-ulang dan diganti warna, serta dicerminkan ke bawah. Jadi bagian atas dan bawah itu adalah sama. Namun jika seseorang melihat dengan proses perhatian yang selektif akan berbeda rasanya. Pada gambar di atas, gambar yang berisi obyek dan bergaris akan terlihat itu adalah figure dan obyek yang tidak bergaris serta terbalik itu adalah ground. Bentuk garis setiap obyek sebagai closure obyek tersebut merupakan garis tanpa putus diteruskan ke bawah menyatu dari bagian atas hingga ke bagian bawah. Selain menyatukan obyek positif (figure) garis tersebut juga mempertegas adanya figure dan ground. Jadi pada 
bagian atas figure terletak di sebelah kanan ground, sedangkan pada bagian bawah figure terletak di bagian kiri, ground terletak di bagian kanan, begitu seterusnya.

Prinsip pengelompokan informasi memungkinkan pengamat untuk mengevaluasi karya berdasarkan atribut yang berbeda sesuai dengan physiological set yang dimiliki. Tiga prinsip grouping untuk mengelompokkan stimulus atau obyek adalah: kedekatan (proximity), kesamaan (similarity) dan kesinambungan (continuity) (Tanudjaja, 2005 :61). Pada gambar di atas prinsip kedekatan terlihat pada obyek-obyek yang disusun memiliki elemen yang saling berdekatan, misalnya bentuk mata yang memiliki bentuk saling berdekatan, bentuk segitiga yang berdekatan, garis hidung serta mulut berdekatan, serta bentuk muka yang hampir sama. Unsur-unsur yang berdekatan disusun tertata sistematis. Jika diamati memiliki perbedaan, namun jika dilihat semua secara utuh dalam satu kesatuan adalah sama. Prinsip kesamaan (similarity) terletak pada unsur bagian atas yang berbentuk segitiga. Kesemuanya segitiga, bagian muka persegi panjang, dan bagian tubuh segitiga. Prinsip kesinambungan (continuity) terletak pada susunan obyek dari kanan ke kiri dengan wajah menghadap ke kiri dan diteruskan ke bagian bawah dari kiri ke kanan dengan wajah menghadap ke kanan. Obyek-obyek yang disusun secara repetisi dan berkesinambungan memiliki alur pengamat dari atas kanan ke kiri, ke bawah kiri menuju kanan.

\section{KESIMPULAN}

Para konsumen dalam memilih produk yang dilihat pertama kali adalah kemasan. Desain kemasan berlomba-lomba menarik perhatian konsumen. Produk sejenis yang disusun berjajar berkelompok akan mengecoh perhatian konsumen dalam menentukan pilihan produk sampai membelinya. Desain kemasan merupakan kemampuan kreatif dalam mengaitkan bentuk, struktur, material, warna, citra, tipografi, dan elemen-elemen desain lainnya yang dikombinasikan dalam informasi produk, supaya produk tersebut dapat dipasarkan. Dalam membuat desain kemasan harus mengetahui jenis produk, karakteristik produk, ketahanan produk, cara memakai produk dan lain-lain. Desain kemasan yang menarik akan mengangkat citra produk. Daya tarik praktis dan daya tarik visual menjadi poin tersendiri seorang konsumen dalam menentukan pilihan produk yang akan dibeli. Para konsumen dan calon konsumen sangat selektif.

Aqua merupakan perusahaan multinasional dalam produksi air mineral memiliki kelas tersendiri, peringkat pertama penjualan kelas air mineral dimiliki oleh Danone yang memproduksi Aqua. Pada usia ke-40 mengajak generasi muda untuk mendesain label kemasan botol $600 \mathrm{ml}$. Generasi muda diajak untuk menggali kekayaan lokal Indonesia yang diangkat dalam karya visual bidang desain grafis salah satunya desain label kemasan. Dari lomba tersebut banyak karya-karya generasi muda bermunculan dan benar-benar dijadikan label kemasan. Salah satu seri pada tema 'temukan Indonesiamu' dengan Judul Berbagi, Santun, Ramah, Kekeluargaan dan Gotong royong. Kelima judul tersebut divisualisasikan dengan gaya ilustrasi yang berbedabeda. Gaya ilustrasi dengan muatan gestalt didalamnya ada dua yaitu kemasan yang berjudul Santun dan Gotong royong. 
Dalam melihat karya yang berjudul Santun dan Gotong Royong tidak bisa dilihat hanya sekilas, setelah diamati secara seksama, beberapa pesan menarik ada di dalam kemasan tersebut. Pesan yang dibawa disajikan dalam bentuk gestalt dimana prinsip persepsi visual ada pada kemasan. Penyajian ilustrasi dengan menuangkan gestalt menjadi daya tarik tersendiri bagi Aqua karena sangat berbeda dengan kemasan atau label minuman air mineral sejenis sebagai produk pesaing. Sehingga saat di display konsumen akan lebih memilih Aqua bukan hanya air mineral yang memiliki branding namun karena adanya daya tarik visual yang lebih menarik dan ingin mengoleksinya.

\section{DAFTAR PUSTAKA}

Aaker, Davis A. 2008. Manajemen Ekuitas Merek: Memanfaatkan Nilai dari suatu Merek. Terjemahan oleh Aris Ananda. Cetakan ketiga. Jakarta : Mitra Utama

Barthes, Roland. 2012. Elemen-elemen Semiologi. Yogyakarta : Jalasutra.

Chaudhuri, Arjun and Holbrook, Morris B 2001. The Chain Of Effects From Brand Trust and Brand Affect to Brand Performance: The Role of Brand Loyalty. Journal of Marketing 65 (2) pp.81-94.

Dameria, Anne. 2014. Packaging Handbook. Jakarta : Link Match Graphic.

Khamadi, K. 2015. Analisis Tampilan Visual Game Super Mario Bros Dalam Kajian Persepsi Visual Sebagai Dasar Pengembangan Konsep Visual Game. ANDHARUPA, 1(2), 98-109.

Kotler,P., \&Amstrong, G. 2012. Principles Of Marketing Edisi 14, Global Edition. Pearson Prentice Hall.

Nathalia, Kirana dan Lia Anggraeni S. 2014. Desain Komunikasi Visual, Dasar-dasar Panduan Untuk Pemula, Bandung,: Nuansa Cendekia.

Sugiyono. 2011. Metode Penelitian Kombinasi. Bandung: Alfabeta.

Tanudjaja, Bing Bedjo. 2005. Aplikasi Prinsip Gestalt Pada Media Desain Komunikasi Visual. Jurnal NIRMANA. 1 (7), pp 56-66.

www.temukanindonesiamu.com diakses 20 Desember 2015 